\title{
Want to Climb Matterhorn? - Train in Blocks
}

\author{
Benedikt Gasser* \\ Swiss Health \& Performance Lab, Institute of Anatomy, University of Bern, Switzerland
}

Submission: February 15, 2018; Published: February 23, 2018

*Corresponding author: Benedikt Gasser, Swiss Health \& Performance Lab, Institute of Anatomy, University of Bern, Switzerland; Tel: +41 31631 84 68; Fax: +413163138 07; Email: gasser@pyl.unibe.ch

\begin{abstract}
Alpinists often practice different disciplines. Often in winter they are backcountry skiing whereas in summer they like climbing. From a physiological point of view these two disciplines have different requirements. Whereas backcountry skiing mainly affords to have a good cardiovascular system uphill and eccentric muscle activity downhill climbing mainly affords to have a good training state mainly in the upper body especially arm flexor musculature. Often during practicing a wish comes up for a challenging goal respectively a difficult mountaineering tour. This often requires special preparation and changes the focus while training to improve the relevant skills in order to increase security. Besides other challenges e.g. psychic such tours often have some more difficult passages, where security can be substantially increased when climbing skills are good. This poses the question how to improve these abilities in a short and effective manner in order to increase security. From a physiological point of view skeletal muscle must be trained respectively force production has to be increased. Due to the fact that alpinists often have a sufficient general training state of cardiovascular system a solid base for strength training exists. Due to the fact that endurance and strength training is perceived by different signal cascades partly inhibiting each other it is therefore recommended that before such a challenging tour such as climbing e.g. Matterhorn a block training of climbing is conducted. This can be done by e.g. bouldering three to four times a week for about 45 minutes. This will within 6 - 8 weeks substantially increase strength and as consequence ability to climb key parts of difficult tours resulting in a more enjoyable and secure way of reaching the mountain.
\end{abstract}

Keywords: Strength versus endurance training; Cortisol; Testosterone

\section{Introduction}

Since some time it's known, that endurance and strength training can inhibit each other [1-4]. Reasons can be detected on molecular level on organ system of skeletal musculature. While endurance training yields to an improvement of better vascularization and to an increase of mitochondria and therefore better ATP regeneration, strength training up regulates myofibrillary proteins. Due to the fact that different stimuli adapt different in strength and endurance signal cascades inhibiting each other, block training is recommended to have substantial improvements in short times. Also, for alpinists block training is recommended especially for alpinists practicing backcountry tours in winter and climbing in summer and now willing to climb a difficult route in the mountains e.g. Matterhorn. Especially, in advance of a difficult tour block training in urbane region e.g. in a boulder hall is recommended in order to improve climbing skills yet increasing security.

\section{A Good Alpinist has Many Skills}

Alpinists often have different interests' eg. Climbing in summer and backcountry skiing in winter. When making sinful training recommendations physiological demands have to be mentioned. Focusing on the physiological demands in climbing the anaerobic strength endurance of the forearm flexor muscles is crucial and represents one main limiting factor [59]. Furthermore possessing greater strength and endurance in the arms and shoulders could be advantageous [10]. Concerning kind of route it can be mentioned that routes with an upward displacement and or a vertical displacement on overhanging wall have highest physiological demands. Elite climbers recorded significantly higher values for finger strength and arm endurance than advanced climbers [11]. Furthermore clear hints exist that training can result in substantial improvement of climbing performance [12]. To keep in mind, success in climbing is not only related to individual physiological variables but is the result of a complex interaction of physiological and psychological factors.

Besides climbing Alpinists often like backcountry skiing. Performance analysis of backcountry skier allow to suggest that due to an often long period of time spent just below and above respiratory compensation threshold ski-mountaineering can be viewed as one of the most strenuous endurance sports like cross-country skiing, running and off-road biking [13]. Analyses from the most popular backcountry race Patrouille des Glaciers in Switzerland confirm the exhaustive character of backcountry 
skiing. Furthermore, often during long-lasting backcountry tours energy balance may be negative and caloric intake is below recommendations [14]. Interestingly, experienced skiers select a speed that minimizes their metabolic cost [15]. To sum up, backcountry skiing requires a good cardiovascular system uphill and a well-developed equilibrium as well as eccentric muscle activity for downhill skiing [16-18].

\section{Strength Versus Endurance Training}

Human skeletal muscle exhibits an outstanding phenotypic plasticity. Endurance training leads to massive increases of mitochondria and improves capillarization. Strength training increases muscle cross-sectional area mainly by increasing myofibrillar proteins [19]. Multiple parallel pathways increasing mainly transcriptional activities for selected muscle proteins are responsible for endurance training related muscle changes. Muscle changes associated with strength training are dominantly achieved by modifying translational mechanisms.

Concurrent effects of strength and endurance training are described. Hickson was already in the 1980 able to show, that parallel training of strength and endurance inhibits strength increase. Furthermore, in mice models it was shown that a high frequent stimulation pattern yields to an activation of AktmTOR-axis, while low frequent stimulation activates AMPK-
PGC-1-System. In training with humans it was elucidated that endurance training immediately before strength training reduces anabolic answer [20]. The effects of repeating stimuli on skeletal muscle are dependent from manner and intensity, whereby through constant stimuli a pooling in some direction seems to take place. This pinpoints the relevance of the premise of block periodization of training and is therefore recommended by different findings.

Coffey 2009 examined acute molecular responses in skeletal muscle to repeated sprint and resistance exercise bouts [21]. Study participants were assigned to trials consisting of either resistance exercise followed by repeated sprints or viceversa. Muscle biopsies from vastus lateralis were obtained at rest, 15 min after each exercise bout, and following 3-h recovery to determine early signaling and mRNA responses. Specifically, initial resistance exercise significantly increased S6K phosphorylation approximately $75 \%$, but there was no effect when resistance exercise was undertaken after sprints. When resistance exercise was followed by repeated sprints PGC1alpha mRNA was increased (Figure 1). To sum up, repeated sprints may promote acute interference on resistance exercise responses by attenuating translation initiation signaling. It was suggested that sprint-activities are isolated from resistance training with allowing training divergent exercise modes.

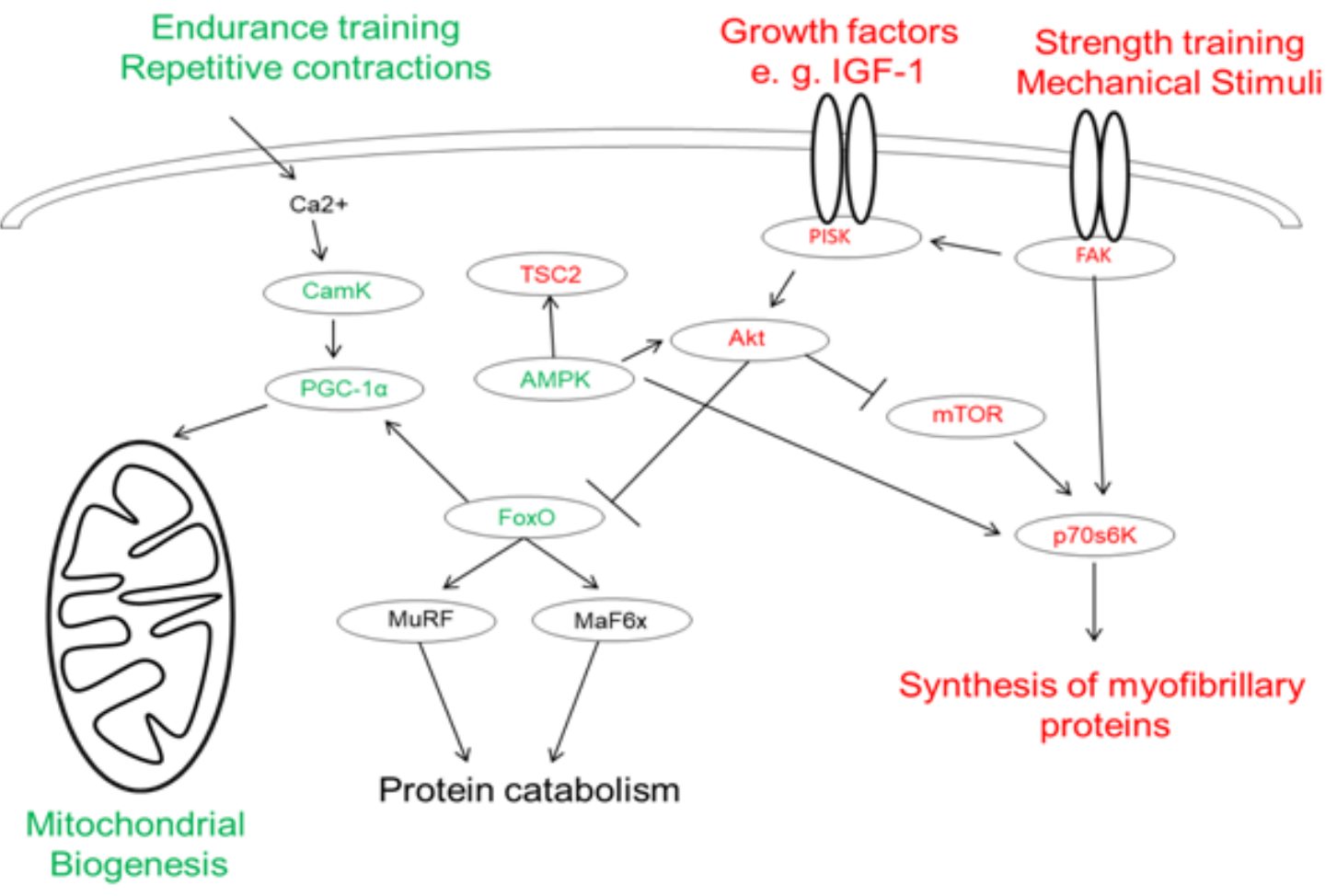

Figure 1: The different way physical stimuli are adapted. Endurance exercise mainly stimulates mitochondrial biogenesis via AMPK System, whereas endurance stimuli are mainly worked by mTOR [14]. In strength training before endurance training inflammation cascades are activated and protein catabolism takes place. Therefore it is recommended to separate strength and endurance training and to train in blocks. 
Describing effects of endurance training it allows performing higher or during a longer time. This requires a higher performance capacity of cardiovascular system. On level of musculature capillarization an improvement can be detected and muscle cells entail more mitochondria. Thus, having muscle cells with more cell organelles responsible for ATP regeneration. As mentioned above the increase of capilarization and mitochondria density is taxed up to $30 \%$. This is an enormous synthesis performance of muscle cells. AMPK can activate PGC1- $\alpha$ (the most important activator of mitochondria biogenesis) and it seems important for cellular homeostasis as well as the transcriptional up regulation under chronic endurance performances [17].

For strength training analyses were conducted. Even after short training interventions of only 6 weeks Isokinetic torque production of the knee extensor muscles increased by a total of $17.6 \%$. The cross-sectional area of the vastus lateralis muscle increased by $8.4 \%$, mainly during the second half of the training period [20]. In contrast, the volume density of mitochondria decreased by $9.6 \%$. Other studies elucidating the relationship between strength and endurance training came to similar findings [3]. To sum up, even strength training seems to yield not only an improvement of strength but also cardiovascular system. This allows implying, that cardiovascular training is a good base for strength training.

\section{Summary}

It seems generally established that molecular adoptions in endurance versus strength training are different. While in endurance training mainly an up regulation of transcriptional factors over PGC- $1 \alpha$ is coordinated, in strength training a translational response is released by mTOR. Furthermore in strength training we see a DNA-recruitment through activation of satellite cells and repressors such as Myostatin and Interleukins. In endurance- and strength training the controlling of molecular adaptions through endurance and strength training is regulated by complex signal paths with multiple input points with parallel signal pathways which are controlled by feedback and feed forward processes. However, a precise mechanistic understanding with prospective meaning is out of view. Different Stimuli strength versus endurance, whereby signal cascades inhibit each other, exist [22-24]. Therefore block training is recommended in order to release substantial improvements within short time. Also for alpinists this form of training is recommended which often make backcountry tours in winter and climbing in summer. Especially before difficult mountaineering tours in order to increase security a short intensive e.g. boulder training block is therefore recommended.

\section{Practical Implications}

a) Mountaineering consists of different performance determining physiological components which can be arbitrarily divided into strength and endurance. b) Due to the fact that the two training regimes endurance and strength can inhibit each other through to different signal pathways partly inhibiting each other, it is recommended to first build a solid cardiovascular base.

c) Shortly before a hard tour it is recommended to train in a block of around 6 - 8 weeks e.g. in a boulder hall in urbane area in order to gain strength and improve security for the difficult climbing parts of a tour e.g. in the Alps such as climbing Matterhorn. In this short time theoretically and practically proven high increases in strength can be achieved increasing security and comfort during a hard mountaineering tour.

\section{References}

1. Atherton PJ, Babraj J, Smith K, Singh J, Rennie MJ, et al. (2005) Selective activation of AMPK-PGC-1alpha or PKB-TSC2mTOR signaling can explain specific adaptive responses to endurance or resistance training-like electrical muscle stimulation. FASEB J 19(7): 786-788.

2. Billat V, Palleja P, Charlaix T (1995) Energy specificity of rock climbing and aerobic capacity in competitive sport rock climbers. J Sports Med Phys Fitness 35(1): 20-4.

3. Coffey VG, Jemiolo B, Edge J, Garnham AP, Trappe SW, et al. (2009) Effect of consecutive repeated sprint and resistance exercise bouts on acute adaptive responses in human skeletal muscle. Am J Physiol Regul Integr Comp Physiol 297(5): R1441-R1451.

4. Drapper N, Gilles D (2015) Comparative grading scales, statistical analyses, climber descriptors and ability grouping: International Rock Climbing Research Association position statement. Sports Technology. Sports Technology 8(34): 88-94.

5. Diaz E, Ruiz F, Hoyos I, Zubero J, Gravina L, et al. (2010) Cell damage, antioxidant status, and cortisol levels related to nutrition in ski mountaineering during a two-day race. J Sports Sci Med 9(2): 338346.

6. Duc S, Cassirame J, Durand F (2011) Physiology of ski mountaineering racing. Int J Sports Med 32(11): 856-863.

7. Durand F, Kippelen P, Ceugniet F, Gomez VR, Desnot P, et al. (2005) Undiagnosed exercise-induced bronchoconstriction in skimountaineers. Int J Sports Med 26(3): 233-237.

8. Fryer S, Giles D, Palomino IG (2017) Hemodynamic and cardio respiratory predictors of sport rock climbing performance. J Strength Cond Res, USA.

9. Fryer S, Stoner L, Stone K (2016) Forearm muscle oxidative capacity index predicts sport rock-climbing performance. Eur J Appl Physiol 116(8): 1479-1484.

10. Giles LV, Rhodes EC, Taunton JE (2006) The physiology of rock climbing. Sports Med 36(6): 529-545.

11. Gutiérrez M, Colás RS, Martínez de Laguna C, Garcés F, González $\mathrm{V}$ (1989) Hematologic repercussions of physical exercise in the mountains. Sangre 34(4): 267-270.

12. Hickson RC (1980) Interference of strength development by simultaneously training for strength and endurance. Eur J Appl Physiol Occup Physiol 45(2-3): 255-263.

13. Holloszy JO, Coyle EF (1984) Adaptations of skeletal muscle to endurance exercise and their metabolic consequences. J Appl Physiol 56(4): 831-838. 
14. Hoppeler HH, Baum O, Mueller M, Lurman G (2011) Molekulare Mechanismen der Anpassungsfähigkeit der Skelettmuskulatur Schweizerische Zeitschrift für Sportmedizin und Sporttraumatologie 59 (1): 6-13.

15. Lüthi JM, Howald H, Claassen H, Rösler K, Vock P, et al. (1986) Structural changes in skeletal muscle tissue with heavy-resistance exercise. Int J Sports Med 7(3): 123-127.

16. Magiera A, Roczniok R, Maszczyk A (2013) The structure of performance of a sport rock climber. J Hum Kinet 36: 107-117.

17. Mermier CM, Janot JM, Parker DL (2000) Physiological and anthropometric determinants of sport climbing performance. Br J Sports Med 34(5):359-365.

18. Ozimek M, Rokowski R, Draga P (2017) The role of physique, strength and endurance in the achievements of elite climbers. PLoS One 12(8): e0182026.

19. Praz C, Léger B, Kayser B (2014) Energy expenditure of extreme competitive mountaineering skiing. Eur J Appl Physiol 114(10): 2201-2211.
20. Rösler K, Hoppeler H, Conley KE, Claassen H, Gehr P, et al. (1985) Transfer effects in endurance exercise. Adaptations in trained and untrained muscles. Eur J Appl Physiol Occup Physiol 54(4): 355-362.

21. Schöffl V, Möckel F, Köstermeyer G (2006) Development of a performance diagnosis of the anaerobic strength endurance of the forearm flexor muscles in sport climbing. Int J Sports Med 27(3): 205-211.

22. Tosi P, Leonardi A, Zerbini L, Rosponi A, Schena F (2010) Energy cost and efficiency of ski mountaineering: A laboratory study. J Sports Med Phys Fitness 50(4): 400-406.

23. Williamson J (2017) Concurrent strength and endurance training. J Phy Fit Treatment \& Sportsl 1(3): 1-5.

24. Zintl F (1997) Ausdauertraining: Grundlagen, Methoden, Trainingssteuerung. Wien Zürich: BLV Sportwissen, Germany.

\section{Your next submission with Juniper Publishers will reach you the below assets}

- Quality Editorial service

- Swift Peer Review

- Reprints availability

- E-prints Service

- Manuscript Podcast for convenient understanding

- Global attainment for your research

- Manuscript accessibility in different formats

( Pdf, E-pub, Full Text, Audio)

- Unceasing customer service

Track the below URL for one-step submission

https://juniperpublishers.com/online-submission.php 